\title{
sciendo
}

CIVIL AND ENVIRONMENTAL ENGINEERING REPORTS

E-ISSN 2450-8594

CEER 2019; 29 (3): 097-106

DOI: $10.2478 /$ ceer-2019-0027

Original Research Article

\section{SOME GEOTECHNICAL PROPERTIES OF PURE AND WASTE GYPSUM FOR GEOELECTRICAL GROUNDING APPLICATIONS}

\author{
Mohd Yuhyi MOHD TADZA ${ }^{1}$, Nurmazuria MAZELAN, Nur Farahana YUSRI, \\ Amizatulhani ABDULLAH \\ Faculty of Civil Engineering and Earth Reources, Universiti Malaysia Pahang \\ Lebuhraya Tun Razak, 26300, Gambang, Kuantan (Pahang)
}

\begin{abstract}
Natural occurring gypsum is a soft mineral consists of hydrated calcium sulphate, mainly used in cement industry. On the other hand, red gypsum (RG) is a waste generated from a sulphate process of ilmenite ore to acquire titanium dioxide. Due to the gypsum content in both materials are similar, it is expected that both gypsum type can be used for similar engineering applications. In this study, RG was tested and compared to pure gypsum for geoelectrical grounding applications. The geotechnical properties and plasticity characteristics were carefully measured and tested. In addition, X-ray fluorescence (XRF) was employed to study the chemical constituents of the materials. Test results showed that, the geotechnical properties of RG is different to that of white gypsum. The plasticity index (PI) of RG was $239.6 \%$ greater due to the presence of Fe ions. Surprisingly, the electrical resistivity of both material were found to be similar. It was also noted that, although the plasticity of pure gypsum is high, the plasticity of pure gypsum was found to be short lived primarily due to instantaneous exothermic reaction between water and semihydrated gypsum. The change in the plasticity also affected the resistivity as gypsum hardened after short duration. Based on the geotechnical and plasticity characteristics determined, RG was found to be a better as grounding material as compared to gypsum.
\end{abstract}

${ }^{1}$ Corresponding author: Faculty of Civil Engineering and Earth Reources, Universiti Malaysia Pahang Lebuhraya Tun Razak, 26300, Gambang, Kuantan (Pahang), dryuhyi@ump.edu.my 
Keywords: gypsum, titanium dioxide, red gypsum, plasticity, grounding, electrical resistivity

\section{INTRODUCTION}

Gypsum is a sulphate based mineral made up of hydrated calcium sulphate, $\left(\mathrm{CaSO}_{4} \cdot 2 \mathrm{H}_{2} \mathrm{O}\right)$. Depending upon the size of the gypsum crystals, gypsum soil layers can have a powdery or a sandy appearance [1]. It is very soft with a Mohr's hardness of about 1.5-2.0. Naturally, gypsum consists of about $21 \%$ water by weight, however this amount of water contributes to about $50 \%$ by volume [2]. While it is hard to establish the amount of soils covering with gypsum in the world, it is estimated that 207 million hectares of soils with gypsum content exist throughout the world [3]. Due to its abundance and unique physical and chemical properties, gypsum is widely used as construction material in many parts of the world [4]. Exposure of gypsum to heat causes it to lose most of its water and form calcium-sulphate hemihydrate $\left(2 \mathrm{CaSO}_{4} \cdot \mathrm{H}_{2} \mathrm{O}\right)$. When mixed with water, gypsum form a paste that dries out and sets to form harder material.

In engineering, gypsum is used in the construction of plasterboards, drywalls and finishing for walls and ceilings. It is commonly added to Portland cement to prevent instantaneous hardening or flash setting [5]. Furthermore, gypsum is used for soil improvements and is used in agriculture as a soil conditioning agent [6]. Apart from that, gypsum is now being utilized as backfill material [7].

Alternatively, Red Gypsum (RG) is a waste material derived from the production of Titanium Dioxide (TiO). RG is produced globally with the same raw material and similar processes. The process of neutralization leads to the generation of a by-product, RG [8]. The red colour imparted by the iron from ilmenite ores (FeTiO) [9]. As compared to normal gypsum, RG have varying states of hydration due to the presence of iron oxide (i.e. 3-35\%) and some other trace elements. Some minor differences in composition were noted due to the presence of impurities or attached other element notably the ilmenite ore.

Currently, RG is regarded as industrial waste and is commonly disposed [10]. In some cases, RG is sold as agricultural soil conditioner, but this application uses only a small proportion of the material produced due to the strict regulatory regime in some countries. Due to the rising cost of disposal, it is essential to find an alternative approach to reutilise RG [11]. In recent years, the applicability of $\mathrm{RG}$ as backfill material was investigated. $\mathrm{RG}$ is considered as a useful waste in civil engineering field [12]. It can replace natural gypsum in the production of cement since it has calcium sulphate as its main component, it can perform the same as natural gypsum and it can even save the usage of clinker in cement up to $4-5 \%$ without lessening a decrease in the quality of cement produced. It was noted 
that, $R G$ have good water retention and plasticity characteristic making it a viable and sustainable material to be utilized or commercialized [13]. It can be an effective binding agent in silty sands when mixed with ground granulated blast furnace slag [11]. RG have acceptable strength, stiffness and a very low permeability that allows it to be used in various civil engineering applications. Another possible use of RG would be, as electrical grounding applications. Information on the use of gypsum or any gypsum based material as grounding material appears to be limited if not available. In recent years, bentonite has been widely accepted and used as backfill material in decreasing and maintaining the low grounding resistance of electrodes for a long time due to its high water absorption and retention characteristics [14-15]. A good ground enhancement material should provide low earth resistance over a long period with little variation of resistivity value [16].

Similar to bentonite, RG have good plasticity and water retention characteristics that makes it as favourable material to be used as electrical grounding. Although Louie et al. [17] noted that gypsum has poor electrical conductivity due to ionic bonding between its cationic and anionic radicals of which it is made, but it is a type of salt with the absence of free electrons. However, Kielmas, [18] noted that gypsum compounds can improve the electrical conductivity of materials. For instance, sensors inserted in the ground can measure local geoelectrical potential. A gypsum coated sensors has been shown to improve the electrical contact between the ground and the sensor. Similarly, gypsum composites showed increased electrical conductivity as compared to pure gypsum [17]. This supports the findings of Guinea et al. [19] that gypsum which contained more impurities showed greater ability to conduct electrical currents.

The applicability of gypsum based material as alternative material for grounding applications has not been well understood. In this study, the geotechnical properties of both gypsum and RG were investigated and identified to be used as geoelectrical grounding material. The objectives of the study were (i) to determine the plasticity characteristics behaviour of both gypsum and RG and (ii) to investigate the performance of both material as grounding material.

\section{TEST METHODS}

\subsection{Characterisations of materials used}

The RG sample was obtained from Venator Materials Corporations, a process plant located in Kemaman, Terengganu, Malaysia, whereas gypsum were procured from a local supplier. General preparation of RG samples would involve pulverising and sieving into powder form passing $425 \mu \mathrm{m}$. On the other hand, 
gypsum samples were obtained in powder form directly from the supplier. The samples were then kept in sealed bags prior to being tested.

Most of the test methods were conducted following BS1377 (1990). The list of test methods carried out is listed in Table 1.

Table 1. Geotechnical and chemical properties test methods

\begin{tabular}{|l|l|}
\hline $\begin{array}{l}\text { Geotechnical } \\
\text { properties }\end{array}$ & Testing Method \\
\hline Specific gravity, $\mathrm{G}_{\mathrm{s}}$ & $\begin{array}{l}\text { Density Bottle (Small pyknometer) method (BS 1377: Part 2 } \\
\text { 1990: 8.3) }\end{array}$ \\
\hline $\begin{array}{l}\text { Particle size } \\
\text { distribution }\end{array}$ & $\begin{array}{l}\text { Simple dry sieving and hydrometer analysis (BS 1377: Part 2: } \\
\text { 1990: 9.3 and 9.5) }\end{array}$ \\
\hline Liquid limit, LL & (BS 1377: Part 2: 1990: 4.3) \\
\hline Plastic limit, PL & (BS 1377: Part 2: 1990: 5.3) \\
\hline Shrinkage limit, SL & $\begin{array}{l}\text { Standard Test Method for Shrinkage Factors of Soils by the Wax } \\
\text { Method (ASTM D4943 - 08) }\end{array}$ \\
\hline Water content, w & Oven drying at 105 ${ }^{\circ}$ C (BS1377: Part 2: 1990) \\
\hline Specific surface area & Wet technique EGME (BS 4359-1:1984) \\
\hline Swell index, C & Free swell test (Gibbs and holtz, 1956) \\
\hline Surface area & Ethylene glycol mono-ethyl ether (EGME) retention method \\
\hline Loss on ignition & (BS 1377: Part 3: 1990: 4.3) \\
\hline Chemical properties & Testing method \\
\hline $\begin{array}{l}\text { Cation exchange } \\
\text { Capacity }\end{array}$ & Ammonium acetate method (Chapman, 1965; Lavkulich, 1981) \\
\hline
\end{tabular}

Chemical properties were obtained by using Cation Exchange Capacity (CEC). The exchanging process means that when there was readily available exchangeable cation, the higher reactivity cations from the solution will replace the adsorbed cation in the soil. CEC is the amount of positive charge attained from $100 \mathrm{~g}$ of dry soil. Therefore, it is usually expressed in meq/100g. In this study, a simplified method suggested by Tadza [20] and ammonium hydroxide solution was used to increase the $\mathrm{pH}$ value to 7 .

In addition to measuring the major ions and CEC values, $x$-ray fluorescence (XRF) analysis was employed to determine the chemical compositions of both material. A Bruker SB Tiger XRF analyser was used for this purpose. Approximately $5 \mathrm{~g}$ of finely grounded specimens placed in a plastic container with a thin film plastic cover layer. The more fine-grained the sample will result in better analysis as void spaces will be limited. 


\subsection{Electrical resistivity measurements}

A Tinker \& Razor soil resistivity meter was used to measure the resistivity of both gypsum based materials under both dry and wet conditions by utilising Wenner 4-point method. For dry conditions, powder specimens were carefully placed into the soil-box apparatus, whereas under wet conditions, the specimens were first mixed with deionized water to each liquid limit values and tested.

\section{RESULTS AND DISCUSSION}

\subsection{Geotechnical and chemical properties}

The Geotechnical and chemical properties of RG and gypsum are presented in Table 2. Referring to Table 2, distinct differences in the geotechnical properties were noted between the two materials. For instance, RG specific gravity value was 3.61 as compared to 2.31 for gypsum. This higher value may be attributed due to the presence of iron. Usually iron rich soil would have high specific gravity in range of 2.75 to 3.0 or even higher (ASTM D 854-92). Normally, calcium carbonate has a specific gravity value of about 2.7. In the case of $R G$, due to higher surface area, a greater CEC value was attained [21]. Similar to highly plastic clays such as bentonite, the higher CEC value also was manifested on the consistency limits (i.e. LL, PL and SL) of RG [22]. This resulted in higher plasticity characteristics compared to gypsum. The plasticity index (PI) values were 33.96 and 10 for RG and gypsum, respectively.

Table 2. Geotechnical and chemical properties of RG testing result

\begin{tabular}{|c|c|c|}
\hline Geotechnical properties & Red Gypsum & Gypsum \\
\hline Specific gravity, $G_{s}$ & 3.163 & 2.31 \\
\hline Particle size distribution & Clay & Clay \\
\hline$>425 \mu \mathrm{m}(\%)$ & 100 & 100 \\
\hline$>63 \mu \mathrm{m}(\%)$ & 100 & 100 \\
\hline$>2 \mu \mathrm{m}(\%)$ & 92 & 97 \\
\hline Liquid limit, $L L(\%)$ & 91.97 & 58 \\
\hline Plastic limit, $P L(\%)$ & 58.28 & 48 \\
\hline Shrinkage limit, $S L(\%)$ & 17.50 & 36 \\
\hline Water content, $w_{i}(\%)$ & 17.25 & 12.3 \\
\hline Specific surface area, $B\left(\mathrm{~m}^{2} / \mathrm{g}\right)$ & 814.72 & 17 \\
\hline Swell index, $C_{s}$ & 0.131 & 0.08 \\
\hline $\begin{array}{lll}\begin{array}{l}\text { Cation } \\
(\mathrm{meq} / 100 \mathrm{~g})\end{array} & \text { exchange capacity } \\
\end{array}$ & 87.63 & 10.00 \\
\hline
\end{tabular}


The higher plasticity could also be attributed as presence of additional cations due to impurities found in RG (see Table 3). Table 3 shows the comparison of chemical compositions of both materials from XRF analyses. These impurities were not detected in gypsum specimens.

A total of 13 different elements (in oxide form) were detected in gypsum as compared to 15 found in RG. In both cases, $\mathrm{CaSO}_{4}$ is the primary element detected. However, additional elements were found in RG, namely the iron oxide component. This brought out the distinct reddish color in RG [9]. Referring to Table 3, 9 other traces element found in RG is primarily derived from ilmenite ores [8].

Table 3. Chemical compositions from XRF analyses

\begin{tabular}{|l|l|l|}
\hline Compound & White Gypsum (wt\%) & Red Gypsum (wt\%) \\
\hline $\mathrm{CaO}$ & 31.00 & 32.20 \\
\hline $\mathrm{SO}_{3}$ & 43.8 & 31.60 \\
\hline $\mathrm{Fe}_{2} \mathrm{O}_{3}$ & 0.2 & 28.99 \\
\hline $\mathrm{TiO}_{2}$ & 0.1 & 5.64 \\
\hline $\mathrm{SiO}_{2}$ & 3.7 & 1.90 \\
\hline $\mathrm{Al}_{2} \mathrm{O}_{3}$ & 0.3 & 0.39 \\
\hline $\mathrm{MgO}$ & 1.0 & - \\
\hline $\mathrm{P}_{2} \mathrm{O}_{5}$ & $<0.1$ & - \\
\hline $\mathrm{Mn}_{2} \mathrm{O}_{3}$ & $<0.1$ & - \\
\hline $\mathrm{CI}$ & 0.1 & - \\
\hline $\mathrm{K}_{2} \mathrm{O}$ & 0.1 & - \\
\hline $\mathrm{Na}_{2} \mathrm{O}$ & 0.1 & - \\
\hline $\mathrm{SrO}$ & 0.2 & - \\
\hline $\mathrm{MnO}^{\mathrm{RuO}}$ & - & 0.41 \\
\hline $\mathrm{RuO}_{2}$ & - & 0.39 \\
\hline $\mathrm{Eu}_{2} \mathrm{O}_{3}$ & - & 0.26 \\
\hline $\mathrm{V}_{2} \mathrm{O}_{5}$ & - & 0.22 \\
\hline $\mathrm{ZrO}_{2}$ & - & 0.06 \\
\hline $\mathrm{CuO}_{\mathrm{HgO}}$ & - & 0.06 \\
\hline $\mathrm{Cr}_{2} \mathrm{O}_{3}$ & - & 0.03 \\
\hline $\mathrm{ZnO}$ & - & 0.03 \\
\hline & - & 0.04 \\
\hline
\end{tabular}

Based on the geotechnical, plasticity and chemical composition of the materials, it is expected that RG and gypsum can perform well as grounding material. These 
characteristics indicated that both RG and gypsum may have good ion (i.e. high CEC) and water retention characteristics (i.e. high LL) which is ideal for parameters for grounding purposes. At microscopic level, the availability of water within the pores of the gypsums would act as interparticle bridging and enhance the flow electrical current [23-24]. This is crucial to dissipate the impulse voltage that is generated during lightning strike.

Ideally, a good grounding material should be (i) highly conductive and/or (ii) have high water retention characteristic [24]. Mitchell [23] reported that electricity is conducted through soil systems in a three-phase manner, namely through particle to particle and through water within pore system. The first mechanism works well for highly conductive material under dry condition, whereas the latter would be more suited for material that able to retain high water (i.e. bentonite).

\subsection{Resistivity measurements}

Table 4 shows the differences between gypsum and RG tested under wet and dry conditions. Under dry conditions, both gypsum and RG shows that the resistivity values were very high (i.e. $>100000 \Omega \mathrm{m}$ ). On the other hand, under wet conditions, the resistivity of RG was slightly lower than that of gypsum indicating that RG have better electrical properties than gypsum. The resistivity value of gypsum although was found to be low, the resistivity value was found to increase with time as water dissipated (dried out) as gypsum hardened.

Table 4. Resistivity measurement

\begin{tabular}{|l|l|l|}
\hline Properties & \multicolumn{2}{|l|}{ Resistivity $(\Omega \mathrm{m})$} \\
\hline & White Gypsum & Red Gypsum \\
\hline Dry condition (hygroscopic water content) & $>100,000$ & $>100,000$ \\
\hline Wet condition (liquid limit water content) & 11 & 8.3 \\
\hline
\end{tabular}

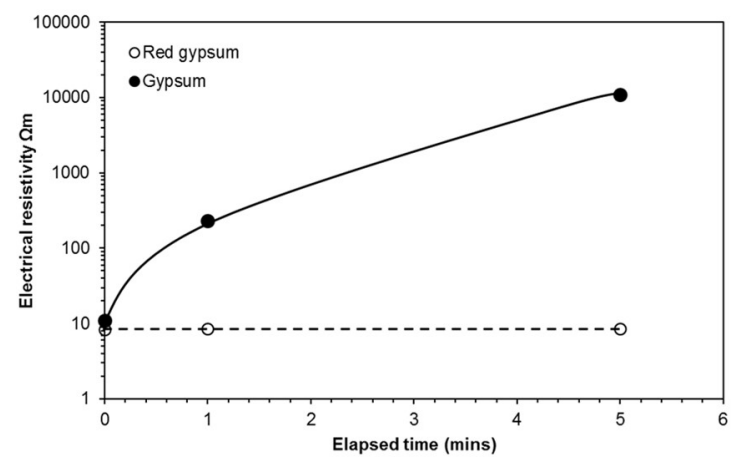

Fig. 1 Evolution of electrical resistivity with elapsed time 
Figure 1 shows the changes in the resistivity value of both RG and gypsum with elapsed time. The resistivity value for gypsum was found to increase significantly within short amount of time (i.e. 5 mins). On the other hand, the resistivity of RG remained stable and somewhat unchanged. It was observed that, RG remained wet throughout the testing period as it did not dried out as gypsum.

When mixed with water gypsum initially turned to plastic slurry and with time, gypsum tended to lose their plasticity characteristics [25]. In this process, the water decreased gradually due to chemical reaction between water and semihydrate gypsum, hydration and evaporation. At the end of the process, gypsum condensed and particle crystallized. As water rapidly evaporated, large number of pores were then generated with the porosity about 50-60\% [26]. As gypsum hardened, the flow of current was truncated. Furthermore, development of pore and increased porosity had caused the electrical resistivity of gypsum to reduce significantly within short period of time. Within minutes, the resistivity value of gypsum reverted back to its original value.

On the contrary, a much lower resistivity value in RG was primarily due to the presence of other impurities and higher available cations (see Table 3). Cizman et al. [27] proved that the large composition of Fe content able to increase the electrical conductivity. When electrical conductivity is higher, the resistivity will be lower. This enables the movement of electrical current to flow through the specimens [28] and improved the grounding functions of RG. Lack of water in gypsum after some time proved to be the main drawback to be used as good grounding material under long-term and would not be a viable material for this purpose. In other words, RG is more suitable to be as grounding material.

\section{CONCLUSIONS}

Based on the findings of this study, the following conclusion were drawn:

The properties of RG and gypsum has been obtained. Initially, the geotechnical properties of RG and gypsum showed promising results as geoelectrical grounding material. However, due to exothermic reaction and evaporation occurred in gypsum, it tends to lose plasticity and water retention characteristics which in turn affected the resistivity value. Similarly, as the process is time dependent and occurred rapidly, gypsum would not make a good grounding material. On the other hand, this aspect was not observed in RG. The high plasticity of RG and the stability of the material was found to perform better as geoelectrical grounding material as compared to gypsum.

\section{ACKNOWLEDGEMENT}

This project was fully funded by Universiti Malaysia Pahang and the Ministry of Education under fundamental research scheme FRGS/1/2017/TK05/UMP/02/2 (RDU170133) and RDU 170343 


\section{REFERENCES}

1. Alphan, JG van and Romero, F. de los R 1971. Gypsiferous soils notes on their characteristics and management, International Institute for Land Reclamation and Improvement, p. 44.

2. Cooper, AH and Calow, RC 1998. Avoiding gypsum geohazards: guidance for planning and construction, Water, p. 57.

3. Herrero, J and Porta, J 2000. The terminology and the concepts of gypsumrich soils, Geoderma, 96(1-2), p. 47-61.

4. Bhamidipati, R 2016. Use Of Laboratory Geophysical And Geotechnical Investigation Methods To Characterize Gypsum Rich Soils. MSc dissertation, University of Kentucky.

5. Samson, G, Phelipot-Mardelé, A and Lanos, C 2017. Thermal and mechanical properties of gypsum-cement foam concrete: effects of surfactant, European Journal of Environmental and Civil Engineering. 21(12), p. 1502-1521.

6. Tang, J et al 2018. An empirical rate law for gypsum powder dissolution, Chemical Geology, 498(September), pp. 96-105.

7. Rahman, M and Ghataora, G 2011. Use of waste gypsum for trench backfill. International Journal of Geotechnical Engineering, 5(4), 405-413.

8. Azdarpour, $\mathrm{A}$ et al 2018. $\mathrm{CO}_{2}$ sequestration through direct aqueous mineral carbonation of red gypsum', Petroleum. Elsevier Taiwan LLC, 4(4), pp. 398 407.

9. Fauziah, I, Zauyah, S and Jamal, T 1996. Characterization and land application of red gypsum: A waste product from the titanium dioxide industry, Science of the Total Environment, 188(2-3), pp. 243-251.

10. Kamarudin, RA and Zakaria, MS 2007. The Utilization of Red Gypsum Waste for Glazes., Malaysian Journal of Analytical Sciences, 11(1), pp. 5764.

11. Hughes, PN et al 2011. Use of red gypsum in soil mixing engineering applications, Proceedings of the Institution of Civil Engineers - Geotechnical Engineering, 164(3), pp. 223-234.

12. August, $\mathrm{AE}$, Noble, $\mathrm{BC}$ and Tooze, JF 2013. Red gypsum in civil engineering applications.

13. Gazquez, MJ et al 2013. Cement \& Concrete Composites Evaluation of the use of TiO 2 industry red gypsum waste in cement production, Cement and Concrete Composites, 37, pp. 76-81.

14. Hasni, NAM, Abd-Rahman, R, Ahmad, H, Jamail, NAM, Kamaruddin, MS and Ridzwan, SS 2017. Investigation of Potential Grounding Compound for Portable Applications. International Journal of Electrical and Computer Engineering, 7(6), 3140.

15. Lim, SC et al 2015. Behaviour of backfill materials for electrical grounding 
systems under high voltage conditions, Journal of Engineering Science and Technology, 10(6), pp. 811-826.

16. Moh Nazar, NS, Thanakodi, S and Muhammad, H 2018. New Waste Material to Enhance the Performance of Grounding System, TELKOMNIKA (Telecommunication Computing Electronics and Control), 15(4), p. 1530.

17. Louie, $\mathrm{O}$ et al 2012. Characterization of the Gypsum Composite for Electrical Conductivity, American Journal of Chemistry, 2(5), pp. 245-247.

18. Keilmas, M 2018. Importance of the Electrical Properties of Gypsum, Leaf Group. Available at: https://sciencing.com/info-12026554-importanceelectrical-properties-gypsum.html.

19. Guinea, A, Playà, E, Rivero, L, Himi, M and Bosch, R 2010. Geoelectrical classification of gypsum rocks. Surveys in geophysics, 31(6), 557-580.

20. Tadza, MYM 2011. Soil-water characteristic curves and shrinkage behaviour of highly plastic clays: an experimental investigation. PhD Thesis, Cardiff University.

21. Tadza, MYM, Azmi, NSM, Mustapha, R, Desa, ND and Samuding, K 2017. Malaysian alternative to international reference bentonite buffer in underground nuclear waste repository. AIP Conference Proceedings 1799(1) p. 030002. AIP Publishing.

22. Tripathy, S, Tadza, MYM and Thomas, HR 2014. Soil-water characteristic curves of clays. Canadian geotechnical journal, 51(8), 869-883.

23. Mitchell, JK and Soga, K 2005. Fundamentals of soil behavior (Vol. 3). Hoboken, NJ: John Wiley \& Sons.

24. Tadza, MM, Mohamad, D, Tripathy, S, Rahman, RA and Ismail, MAM 2019. Bentonite and marconite for electrical grounding applications from geotechnical engineering perspective. In AIP Conference Proceedings 2129(1), 020078. AIP Publishing.

25. Zhang, H 2011. Building materials in civil engineering. Elsevier.

26. Schilling, $\mathrm{CH}$ 2001. Colloid Casting in Encyclopedia of Materials: Science and Technology.

27. Cizman, A et al 2017. The effect of $\mathrm{Fe}$ on the structure and electrical conductivity of sodium borosilicate glasses, Physical Chemistry Chemical Physics, 19(34), pp. 23318-23324.

28. Rahimi, S and Siddiqua, S 2017. Relationships between degree of saturation, total suction, and electrical and thermal resistivity of highly compacted bentonite. Journal of Hazardous, Toxic, and Radioactive Waste, 22(2), 04017025. 